\title{
Correction to: First confirmation of rabies in Zamfara State, Nigeria-in a sheep
}

\author{
Ibrahim Ahmad ${ }^{1}$ Caleb Ayuba Kudi ${ }^{2}$ Muktar Salihu Anka ${ }^{1} \cdot$ Ishaya S. Tekki $^{3}$
}

Published online: 18 October 2017

(C) Springer Science+Business Media B.V. 2017

\section{Correction to: Trop Anim Health Prod (2017) 49:659-662 https://doi.org/10.1007/s11250-017-1233-8}

Unfortunately the Abstract was missing in the original version of this article. The Abstract is published below.

\begin{abstract}
The first case of rabies virus (RABV) infection was identified in Zamfara State Nigeria, in August 2015. A sheep was exposed to RABV consequence of a mad-dog bite. Barely a month after the bite wound had healed-off the sheep owner filed a complaint to Gusau veterinary clinic of ob-
\end{abstract}

served neurological signs and in-appetence on the animal. Signs suspicious of rabies such as unilateral corneal opacity of the right eye, muscular tremors, hydrophobia and salivation were further observed on clinical examination. Variableshaped viral antigens were detected from the brain tissues by fluorescent antibody test (FAT), and the presumptive diagnosis of RABV infection was confirmed by a positive FAT result. This report describes ruminant (sheep) rabies, its mode of transmission and subsequent public health implications. Control and prevention of this deadly disease in domestic dogs and livestock need to be stepped up.

The online version of the original article can be found at https://doi.org/ $10.1007 / \mathrm{s} 11250-017-1233-8$

Ibrahim Ahmad

ibrahimahmaad22@gmail.com

1 Directorate of Animal Health and Livestock Development, Old Cabinet Office, Canteen Area, Gusau, Zamfara, Nigeria

2 Department of Veterinary Medicine, Faculty of Veterinary Medicine, Ahmadu Bello University, Zaria, Kaduna, Nigeria

3 Rabies Diagnostic Laboratory, National Veterinary Research Institute Vom, Jos, Nigeria 